\title{
BIBECHANA
}

ISSN 2091-0762 (Print), 2382-5340 (Online)

Journal homepage: http://nepjol.info/index.php/BIBECHANA

Publisher: Department of Physics, Mahendra Morang A.M. Campus, TU, Biratnagar, Nepal

\section{Facile methods of preparing pure hydroxyapatite nanoparticles in ordinary laboratories}

\author{
Gokarna Pandey ${ }^{1}$, Kedar Nath Dhakal, Ajaya Kumar Singh ${ }^{2}$, Suresh Kumar Dhungel ${ }^{3}$, \\ Rameshwar Adhikari ${ }^{1,4}$ * \\ ${ }^{1}$ Central Department of Chemistry, Tribhuvan University (TU), Kirtipur, Kathmandu, Nepal \\ ${ }^{2}$ Department of Chemistry, Govt. V. Y. T. PG Autonomous College, Durg, Chhattisgarh, India \\ ${ }^{3}$ Nepal Academy of Science and Technology (NAST), Lalitpur, Nepal \\ ${ }^{4}$ Research Centre for Applied Science and Technology (RECAST), TU, Kirtipur, Kathmandu, Nepal \\ *Email: ram.adhikari.tu@gmail.com
}

\section{Article Information}

Received: June 1, 2020

Accepted: July 2, 2020

\section{Keywords}

Hydroxyapatite

Nanoparticles

FTIR spectroscopy

X-ray diffraction

Bioceramic

\begin{abstract}
The present work features some simple methods of preparing pure hydroxyapatite nanoparticles (nano-HAp), a useful biomaterial, via various wet chemical methods and using biogenic sources such as eggshells and animal bone. The nano-HAp hence prepared was subsequently characterized by FTIR spectroscopy and XRD technique. The FTIR spectra confirmed the presence of $\mathrm{PO}_{4}{ }^{3-}$ and $\mathrm{OH}^{-}$ ions as major functional groups in the prepared material, with some additional peaks implying the presence of $\mathrm{CO}^{3-}$ ions and adsorbed water molecules. The XRD patterns, in agreement with the JCPDS 09-432 data, demonstrated the crystalline nature of the nano-HAp and confirmed the phase as being apatite. The average grain diameter of the nanocrystallites was found in the range of 15-30 $\mathrm{nm}$. The preparatory methods depicted herein can be easily employed in ordinary high school laboratories having basic facilities such as availability of distilled water, some handy glasswares, common laboratory chemicals and instruments such as balance, hot air oven and furnace.
\end{abstract}

DOI: https://doi.org/10.3126/bibechana.v18i1.29600

This work is licensed under the Creative Commons CC BY-NC License. https://creativecommons.org/licenses/by-nc/4.0/

\section{Introduction}

Hydroxyapatite (HAp), with the chemical formula $\mathrm{Ca}_{10}\left(\mathrm{PO}_{4}\right)_{6}(\mathrm{OH})_{2}$, is one of the most attractive bioceramics for several biomedical applications due to its osteoconductive and antimicrobial properties and biocompatibility as well as lack of toxic and inflammatory responses [1-4]. HAp is the major mineral constituent of human bone accounting for approximately 65 weight fraction of the latter.
Bone is, in fact, a nanocomposite material comprising HAp mineral and collagen proteins, its properties thus largely being dependent on the nanoscale morphology. The apatite crystals are the essential parts of tooth and bone of all the vertebrates. When used as implants, the synthetic HAp is able to provide a scaffold or template for new bone regeneration and growth, and supports the osteoblast adhesion and proliferation $[3,4]$. 
Such an important bio-ceramic can be synthesized either from natural sources such as bone, corals, eggshells, body fluids, etc. or via various chemical routes including sol-gel method, mechano-chemical precipitation, hydrothermal technique, flame spray and microwave assisted method, and others [2-16].

The major mineral constituents of human bone are calcium and phosphorous with traces of other substances [17,18]. However, a considerable amount of carbonate $\left(\mathrm{CO}_{3}{ }^{2-}\right)$ also appears to be present in the bone. The presence of $\mathrm{CO}_{3}{ }^{2-}$ ions in biological apatite is of great importance because it is the main source of lattice distortion, creating micro-stresses and crystalline defects in its surrounding area which, in turn, play a vital role in its solubility. Thus, synthetic apatite should exhibit small particle size and presence of $\mathrm{CO}_{3}{ }^{2-}$ [18].

It has been demonstrated that the nanocrystalline HAp (nano-HAp) exhibits enhanced biocompatibility, bioactivity and mechanical performance over microcrystalline or bulk HAp, which has been attributed to their unique quantum confinement effects and large surface area to volume ratio. Thus the nano-HAp can be used in designing superior biocompatible coatings for the implants and in developing high strength composite materials $[4,12,17,18]$.

With the dawn of nanotechnological revolution during last few decades, and in context of unparalleled opportunities offered by these technological advances also in developing countries, the facile methods for nanomaterials synthesis are of tremendous scientific importance. There is overwhelming interest in the versatile routes for the synthesis of such materials among young scientists in their early career. Taking into account the vigor of scientists of new generation towards nanomaterials and their technological implications, the objective of present work has been to demonstrate simple methods of preparing nano-HAp in ordinary high school laboratories also using wet chemical methods by utilizing biogenic waste as resources. As evidence for the success of the methods used, the characterization of the materials by Fourier transform infrared (FTIR) spectroscopy and X-ray diffraction (XRD) are reported here.

\section{Experimental Section}

\subsection{Materials}

Analytical grade calcium nitrate tetrahydrate, diammonium hydrogen phosphate, ammonium hydroxide (25\%), ortho-phosphoric acid (85\%), urea, calcium oxide, ethanol and ethylene-diaminetetraacetic acid (EDTA) were purchased from Merck India Ltd. Egg shells and adult buffalo femoral bones were collected from local market in Kathmandu. All solutions were prepared in distilled water.

\subsection{Preparation of nano-HAp}

Four different methods used for the preparation of nano-HAp were sol-gel method, precipitation method using calcium oxide and ortho-phosphoric acid as starting materials, precipitation method using aqueous slurry comprising of egg-shells powder and ortho-phosphoric acid solution, and calcination of animal bone.

\section{(a) Sol-gel Method}

This method was adopted from different research articles $[11,12,19,20]$ published elsewhere. In this method, $10.8 \mathrm{~g}$ of calcium nitrate tetrahydrate, $\mathrm{Ca}\left(\mathrm{NO}_{3}\right)_{2} \cdot 4 \mathrm{H}_{2} \mathrm{O}$ and $3.89 \mathrm{~g}$ of diammonium hydrogen phosphate, $\left(\mathrm{NH}_{4}\right)_{2} \mathrm{HPO}_{4}$ were separately dissolved in $50 \mathrm{~mL}$ of water taken in a $100 \mathrm{~mL}$ conical flask for each. Phosphate solution was then added drop-wise to the calcium nitrate solution maintained at temperature of $75{ }^{\circ} \mathrm{C}$. The $\mathrm{pH}$ was maintained at 11 throughout the experiment using ammonia solution. The resulting solution was continuously stirred for $2 \mathrm{hrs}$ and the product was allowed to cool and precipitate for $24 \mathrm{hrs}$. The aged gel thus obtained was filtered and washed with doubly distilled water and ethanol several times till the filtrate was neutral. Finally, the resulting clear white powder was stored in a hot air oven 
maintained at $85{ }^{\circ} \mathrm{C}$ for $12 \mathrm{hrs}$ for further analyses. $10 \mathrm{Ca}\left(\mathrm{NO}_{3}\right)_{2}+6\left(\mathrm{NH}_{4}\right)_{2} \mathrm{HPO}_{4}+8 \mathrm{NH}_{4} \mathrm{OH}$

$\longrightarrow \mathrm{Ca}_{10}\left(\mathrm{PO}_{4}\right)_{6}(\mathrm{OH})_{2}+20 \mathrm{NH}_{4} \mathrm{NO}_{3}+6 \mathrm{H}_{2} \mathrm{O}$

\section{(b) Precipitation Method}

This method was adopted on the basis of works reported elsewhere [2,5,17,21,22]. Calcium oxide $(\mathrm{CaO})$, ortho-phosphoric acid $\left(\mathrm{H}_{3} \mathrm{PO}_{4}\right)$, and ammonium hydroxide $\left(\mathrm{NH}_{4} \mathrm{OH}\right)$ were used as starting substances for this method. First of all, $7.955 \mathrm{~g}$ of dry $\mathrm{CaO}$ powder was added to $50 \mathrm{~mL}$ of water taken in a $100 \mathrm{~mL}$ conical flask and vigorously stirred at $20{ }^{\circ} \mathrm{C}$ for $24 \mathrm{hrs}$ to form aqueous suspension of $\mathrm{Ca}(\mathrm{OH})_{2}$. Then $9.732 \mathrm{~g}$ of $85 \% \mathrm{H}_{3} \mathrm{PO}_{4}$ was slowly added to the solution at a rate of about $1.5 \mathrm{~mL} / \mathrm{min}$. The reactants were further stirred for $24 \mathrm{hrs}$ to attain the maturation stage, under constant stirring. The $\mathrm{pH}$ of the solution was maintained at 10 using ammonia solution. The precipitate was filtered, washed and dried in hot air oven at $85{ }^{\circ} \mathrm{C}$ for $12 \mathrm{hrs}$. The chemical reaction may be written as:

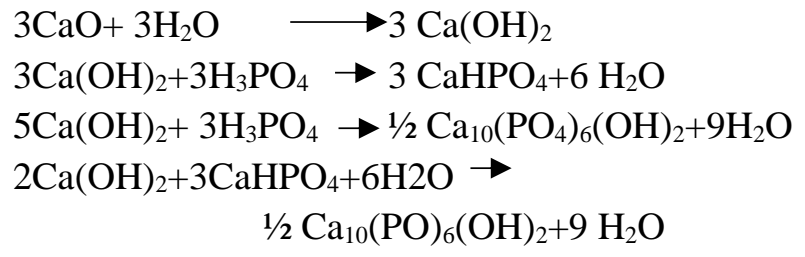

\section{(c) Eggshells as Starting Material}

An eggshell that primarily comprises of calcium carbonate $\left(\mathrm{CaCO}_{3}\right)$ can be converted into calcium oxide $(\mathrm{CaO})$ via calcination, which can be then used as an inexpensive raw material for the HAp synthesis. Following the methods reported in elsewhere [6,23-25], the chicken eggs shells were collected and cleaned with tap water followed by washing with distilled water and acetic acid solution several times and dried and powdered using a grinder.

The powder was hence subjected to thermal treatments in a furnace in three stages: firstly, at $150{ }^{\circ} \mathrm{C}$ for $5 \mathrm{hrs}$ to remove water and organic impurities, secondly, at $500{ }^{\circ} \mathrm{C}$ for $3 \mathrm{hrs}$ to remove
The reaction can be represented as: any remaining organic residue, and finally at 1000 ${ }^{\circ} \mathrm{C}$ for $2 \mathrm{hrs}$ to transform the eggshell powder to $\mathrm{CaO}$. The powder was then transformed into HAp in the phosphate solution using the following procedure.

$5 \mathrm{~g}$ of calcium oxide was dissolved under constant stirring in $6 \mathrm{~g}$ of ortho-phosphoric acid. Then $0.4 \mathrm{~g}$ of urea was added along with $0.8 \mathrm{~g}$ of EDTA and $100 \mathrm{~mL}$ of water. The $\mathrm{pH}$ of the solution was adjusted to 10 using ammonia solution at $75^{\circ} \mathrm{C}$.

The reaction mixture was further stirred for half an hour and then kept relaxed for 24 hrs to allow nano-HAp to grow. The slurry was centrifuged at $5000 \mathrm{rpm}$ for $2 \mathrm{~min}$ and the resulting sludge was thoroughly washed with distilled water until neutral $\mathrm{pH}$. The precipitate was dispersed in $100 \mathrm{~mL}$ of ethanol and the mixture was sonicated for $1 \mathrm{hr}$. The residue was dried in air for $24 \mathrm{hrs}$ and then at $85^{\circ} \mathrm{C}$ in an oven for $12 \mathrm{hrs}$. The reaction may be written as:

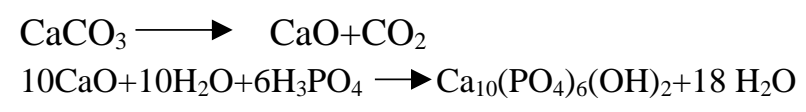

\section{(d) Animal Bone as Starting Material}

This method was adopted from different research papers [16,26-28]. Briefly, the femoral bones of buffalo was collected from butcher shop that were then cut into small pieces and boiled in water for 3 hrs. The bone was then washed with acetone for several times to remove fats and other impurities and hence dried at $160{ }^{\circ} \mathrm{C}$ for $48 \mathrm{hrs}$. The pieces were ground to powder with particle diameter less than $450 \mu \mathrm{m}$. The powder was treated with $4 \mathrm{M}$ $\mathrm{NaOH}$ (solid-liquid weight ratio of 1.40) for deproteinization. The content was heated at $250{ }^{\circ} \mathrm{C}$ for $5 \mathrm{hrs}$.

The defatted and deproteinized powder was calcined at $700{ }^{\circ} \mathrm{C}$ for $6 \mathrm{hrs}$ in a muffle furnace to obtain grayish white powder of HAp. The powder was further calcined at $1000{ }^{\circ} \mathrm{C}$ for another $6 \mathrm{hrs}$ to study the effect of calcination temperature.

\subsection{Methods for characterization}


Fourier Transform Infrared (FTIR) Spectroscopy

The FTIR analysis was performed by using a Prestige-21 FTIR Spectrometer (Shimadzu Company, Japan). The spectra were collected in the range of $4700-400 \mathrm{~cm}^{-1}$ using $\mathrm{KBr}$ pellet method.

\section{X-Ray Diffraction (XRD)}

The crystal phase and structure of the samples were determined by Bruker D2 Phaser X-ray diffractometer with a monochromatic $\mathrm{CuKa}$ radiation source $(\lambda=0.15418 \mathrm{~nm})$ with $2 \theta$ angles ranging from $20^{\circ}$ to $80^{\circ}$. The accelerating voltage of $30 \mathrm{kV}$ and emission current of $10 \mathrm{~mA}$ were used.

\section{Results and Discussion}

The phase purity and presence of major functional groups of the HAp powder were attested by FTIR analyses. Fig. 1 shows the FTIR spectrum of the HAp powder chemically synthesized by sol-gel method.

The spectrum is dominated by the typical $\mathrm{PO}_{4}{ }^{3-}$ bands of crystalline apatite phase characterized by the peaks representing triply degenerate $v_{3}\left(\mathrm{PO}_{4}{ }^{3-}\right)$ asymmetric mode centered at $1021 \mathrm{~cm}^{-1}$ and 1087 $\mathrm{cm}^{-1}$ (shoulder), non-degenerate symmetric stretching mode $v_{1}\left(\mathrm{PO}_{4}{ }^{3-}\right)$ at $962 \mathrm{~cm}^{-1}$ and components of the triplet of $\mathrm{v}_{4}\left(\mathrm{PO}_{4}{ }^{3-}\right)$ bending modes at $560 \mathrm{~cm}^{-1}$ and $470 \mathrm{~cm}^{-1}$ $[2,6,12,21,23,29,30]$. The broad band located between $3200-3600 \mathrm{~cm}^{-1}$, together with weak and broad band around $1627 \mathrm{~cm}^{-1}$ of $\mathrm{H}-\mathrm{O}-\mathrm{H}$ bending mode indicates the presence of absorbed water. The weak peak located at $3570 \mathrm{~cm}^{-1}$ corresponds to the vibrations of $\mathrm{OH}^{-}$ions in the HAP lattices $[6,24,26]$.

The two peaks centered near 1490 and $1426 \mathrm{~cm}^{-1}$ are assigned to the $v_{3}$ vibration mode and the weak peak at about $870 \mathrm{~cm}^{-1}$ is due to the $v_{2}$ vibration mode of free, planar $\mathrm{CO}_{3}{ }^{2-}$ ions (group symmetry $\left.\mathrm{D}_{3} \mathrm{H}\right)$ [12,20,23-25]. The weak band at $2360 \mathrm{~cm}^{-1}$ can be attributed to $\mathrm{C}=\mathrm{O}$ bonds from adsorbed atmospheric carbon dioxide [25].

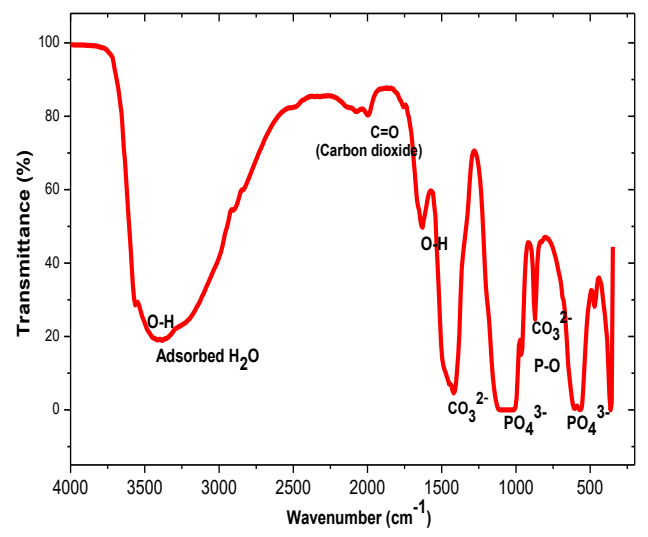

Fig. 1: FTIR spectrum of HAp powder synthesized by sol-gel method.

In summary, the FTIR spectrum shown in Fig. 1 verifies, in consistence with several literatures, the success of the chemical synthesis of the HAp powder. Fig. 2 shows a closer look on structure of the raw eggshell and the HAp.

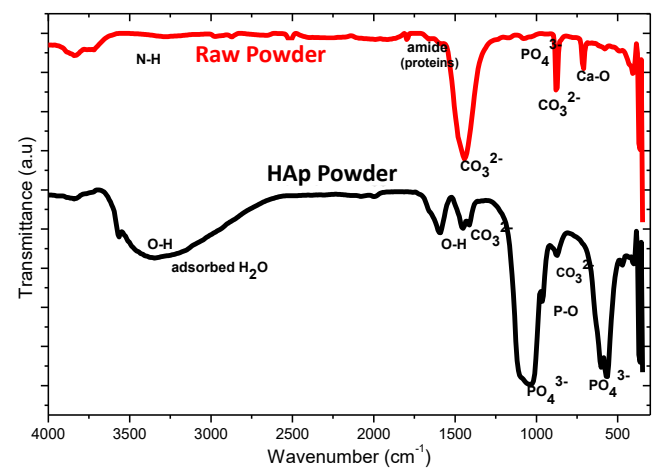

Fig. 2: FTIR spectra of raw eggshells powder compared with the HAp from eggshells.

The IR spectrum of the raw eggshell shows the strong carbonate peaks centered at $1490 \mathrm{~cm}^{-1}$ and $870 \mathrm{~cm}^{-1}$, and the sharp peak located at $710 \mathrm{~cm}^{-1}$, which represents the absorbance by $\mathrm{Ca}-\mathrm{O}$ bond [31].

The weak band at $2360 \mathrm{~cm}^{-1}$ is attributed to $\mathrm{C}=\mathrm{O}$ bonds from carbonate $[25,32]$ while the broad band at around $2863 \mathrm{~cm}^{-1}$ appears due to $\mathrm{OH}$ stretching vibration and that around $3600 \mathrm{~cm}^{-1}$ arises due to $\mathrm{N}-\mathrm{H}$ bonds due to proteins present in the raw eggshells. 
The IR spectrum of the HAp powder prepared from eggshells given towards the bottom of Fig. 2 is much different from the spectrum of raw eggshells as expected but contains the noteworthy peaks related to the HAp phosphates such as those centered around 470, 560, 1020, and $1090 \mathrm{~cm}^{-1}$, as compared with Fig. 1.

Fig. 3 shows the FTIR spectra of buffalo bone powder and the HAp prepared from it. Unlike in the eggshells, the spectrum of the buffalo bone powder, as shown in upper part of Fig. 3, clearly shows the presence of phosphate peaks centered at $1090,1040,603,568 \mathrm{~cm}^{-1}[10,32,33]$ as well as $\mathrm{OH}$ group at $3570 \mathrm{~cm}^{-1}[12,26,34]$ confirming the presence of hydroxyapatite as a major mineral component in the buffalo bone.

The presence of sharp peaks in the aliphatic zone (2924 $\mathrm{cm}^{-1}$ and $2875 \mathrm{~cm}^{-1}$ ) due to the $\mathrm{C}-\mathrm{H}$ elongation vibration together with the weak peaks at $1654 \mathrm{~cm}^{-1}$ due to the elongation vibration of $\mathrm{C}=\mathrm{O}$ bonds and at $1541 \mathrm{~cm}^{-1}$ due to the deformation vibration of $\mathrm{N}-\mathrm{H}$ bonds and elongation of $\mathrm{C}-\mathrm{N}$ bonds in the bone powder results from the collagen protein [33-35].

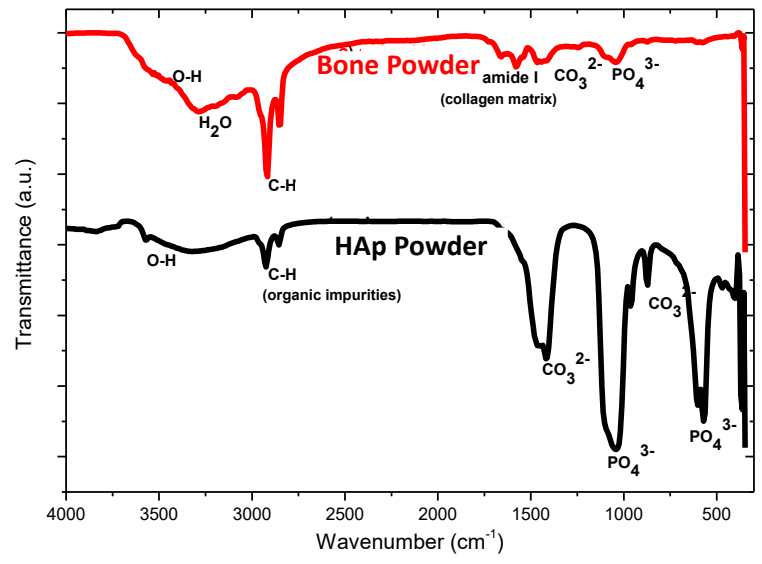

Fig. 3: Comparison of the FTIR spectra of bone powder and HAp prepared there from.

Likewise, the presence of broad bands in the range of $3200-3600 \mathrm{~cm}^{-1}$ result from adsorbed water and carbonate band located at $1450 \mathrm{~cm}^{-1}$ arises due to the presence of $\mathrm{CaCO}_{3}$ in the buffalo bone [35].
The spectrum is very much similar to that of HAp obtained from eggshells and sol-gel method except that it contains additional $\mathrm{C}-\mathrm{H}$ peaks $\left(2924 \mathrm{~cm}^{-1}\right.$ and $2875 \mathrm{~cm}^{-1}$ ), which can be linked to the presence of residual organic impurities. The presence of carbonate peak $\left(1450 \mathrm{~cm}^{-1}\right.$ and $\left.870 \mathrm{~cm}^{-1}\right)$ [35] might imply that it still contains $\mathrm{CaCO}_{3}$ as impurity in the resulting HAp powder, which will be later confirmed by XRD spectra as shown in Fig. 5.

Fig. 4 shows the XRD patterns of HAp powder synthesized by three different chemical methods: sol-gel method, precipitation method using eggshell and wet chemical precipitation method using $\mathrm{CaO}$ and $\mathrm{H}_{3} \mathrm{PO}_{4}$ as starting materials.

The XRD patterns show that all the synthesized HAp materials are crystalline. The peaks located at $2 \theta$ values of $26^{\circ}, 29^{\circ}, 32^{\circ}, 34^{\circ}, 40^{\circ}, 47^{\circ}, 50^{\circ}, 53^{\circ}$ and $64^{\circ}$, correspond to (002), (102), (211), (112), (202), (310), (222), (213) and (004) Miller reflection planes of HAp, respectively (which comply with the JCPDS 09-432 data) $[2,5,6,10,12,19,23,27,30,36]$.

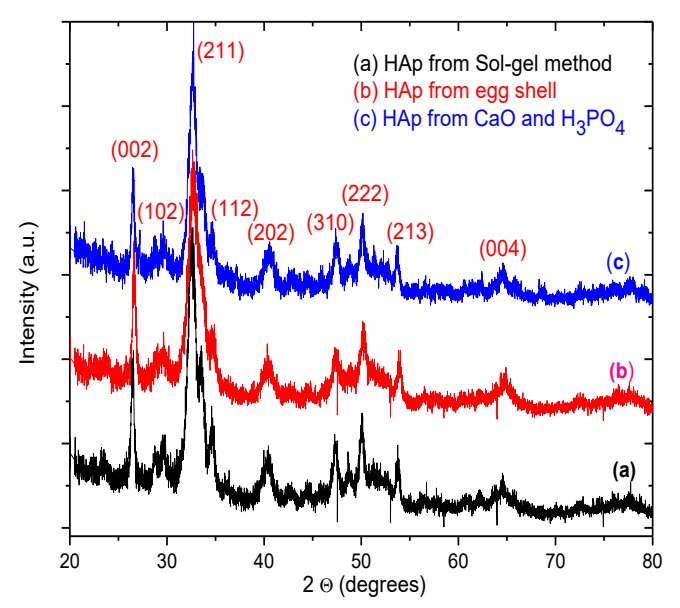

Fig. 4: XRD pattern of HAp powder synthesized by different methods as indicated.

It is quite interesting to note that all the investigated samples have quite similar XRD patterns confirming the presence of the pure apatite phase in 
the prepared samples. The absence of peaks corresponding to (024), (021) etc. planes also

clearly hinted the absence of phases such as $\beta$ tricalcium phosphate [36].

The XRD patterns of the HAp from eggshell powder shows comparatively less impurities than from other methods which confirms that the impurities content in HAp can be reduced byheating the powder at higher temperatures, the same deduction as indicated by the FTIR results.

Fig. 5 shows the XRD pattern of HAp samples obtained from bone powder calcined at two different temperatures, $700{ }^{\circ} \mathrm{C}$ and $1000{ }^{\circ} \mathrm{C}$. XRD patterns of both samples are very similar to that obtained by chemical methods. However, the presence of a quite sharp peak located at $2 \theta$ value of $29^{\circ}$ in the HAp prepared by calcination of the bone powder at $700{ }^{\circ} \mathrm{C}$ indicates the presence of considerable amount of $\mathrm{CaCO}_{3}$.

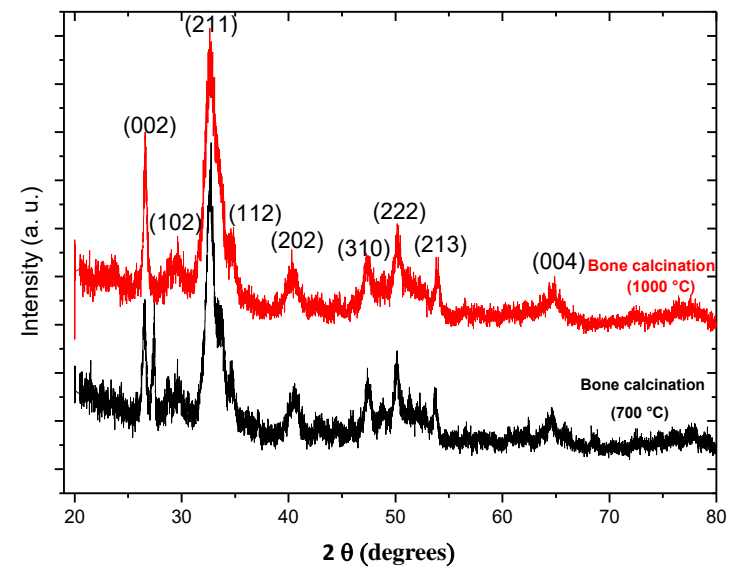

Fig. 5: XRD patterns of HAp obtained from buffalo bone after calcination at $700{ }^{\circ} \mathrm{C}$ and $1000{ }^{\circ} \mathrm{C}$.
This peak, however, almost disappears when same HAp powder is heated at $1000{ }^{\circ} \mathrm{C}$, indicating that the decomposition of $\mathrm{CaCO}_{3}$ takes place at higher temperature. Further, the HAp peaks were found to become sharper with increasing calcination temperature. The results imply the advantages of attaining better purity of the HAp by calcination of the bone powder at higher temperature.

The diffraction peak observed at $2 \theta$ angle of $32^{\circ}$ corresponding to the (211) plane, was chosen for the calculation of the crystallites size, as the former peak can be isolated from other peaks and is relatively sharper than the others. The average crystallite diameter was calculated by using DebyeScherrer formula as reported elsewhere [12]:

$$
\tau=\mathrm{K} \lambda / \beta \cos \theta
$$

where, ' $\tau$ ' is the average crystallite size (in $\mathrm{nm}$ ), ' $\mathrm{K}$ ' is the shape factor $(\mathrm{K}=0.9$ for most of the spherical crystallites), ' $\lambda$ ' is the wavelength of the $\mathrm{X}$-rays $\left(\lambda=1.54056 \AA\right.$ for $\mathrm{Cu} \mathrm{K}_{\alpha}$ radiation), ' $\beta$ ' is the full width at half maximum (FWHM) (in radian) and ' $\theta$ ' is the Bragg's diffraction angle. Table 1 compares the crystallite size of HAp particles prepared by various methods.

It can be seen that size of the crystallites prepared by different methods lies in the range of 15-30 nm. The HAp synthesized by sol-gel method was found to have smallest crystallite size while the buffalo bone powder calcined at $1000{ }^{\circ} \mathrm{C}$ produced the largest crystallites. However, the size disparity is not too large. The bone calcined at $100{ }^{\circ} \mathrm{C}$ has produced the crystals slightly larger than that calcined at $700{ }^{\circ} \mathrm{C}$. There might also be some other factors affecting the nano-crystal size during the synthesis.

Table 1: Average crystallite size of HAp prepared by various methods calculated using equation (i).

\begin{tabular}{clcc}
\hline S. No. & Methods & $\mathbf{2 \theta}\left({ }^{\circ}\right)^{*}$ & Crystallite size (nm) \\
\hline 1 & Sol-gel & 32.668 & 14.80 \\
2 & Precipitation & 32.796 & 28.11 \\
3 & Eggshell & 32.647 & 17.51 \\
4 & Bone (powder calcined at $700^{\circ} \mathrm{C}$ ) & 32.748 & 18.06 \\
5 & Bone (powder calcined at $\left.1000^{\circ} \mathrm{C}\right)$ & 32.942 & 29.23 \\
\hline
\end{tabular}

* $2 \theta$ values corresponding to (211) Miller planes at around $32^{\circ}$ for each sample 


\section{Conclusions}

A comparative study on simple, inexpensive, and facile approaches for the synthesis of nano-HAp has been presented. It has been demonstrated that the nano-HAp with reasonably high crystallinity and purity can be prepared in an ordinary senior high school chemistry laboratory. Among the methods presented, the procedure employed on the animal bone offers reliable, most cost effective and greener way of preparing the nano-HAp with high degree of purity and yield.

The FTIR spectra of all HAp samples showed typical peaks centered around 470, 560, 960, 1020 and $1090 \mathrm{~cm}^{-1}$ corresponding to phosphate groups of apatite phase. All the specimens showed the presence of adsorbed water (band 3200-3600 $\mathrm{cm}^{-1}$ ) and vibration of $\mathrm{OH}$ - ions (3570 and $\left.1027 \mathrm{~cm}^{-1}\right)$ in HAp lattices. The presence of peak corresponding to carbonate ions (1426-1490 and $870 \mathrm{~cm}^{-1}$ ) revealed the presence of impurities that might not appear on performing the experiment under inert atmosphere.

The XRD results showed that all the synthesized HAp samples were fairly nano-crystalline which also matched the corresponding (JCPDS 09-432) files for apatite crystals with corresponding (002), (102), (211), (112), (202), (310), (222), (213) and (004) lattice planes. The crystallite size of the HAp was in the range $15-30 \mathrm{~nm}$.

\section{Acknowledgments}

We thank Department of Plant Resources, Thapathali, Kathmandu for the FTIR characterization of the materials.

\section{References}

[1] S.V. Dorozhkin, Calcium orthophosphates as bioceramics: state of the art., J. Func. Biomaterials 31 (2010) 22-107. https://doi.org/10.3390/jfb1010022

[2] A. B. H. Yoruç, Y. İpek, Sonochemical synthesis of hydroxyapatite nanoparticles with different precursor reagents. Acta Physica Polonica A 121 (2012) 230-232.

[3] B. Viswanath, N. Ravishankar, Controlled synthesis of plate-shaped hydroxyapatite and implications for the morphology of the apatite phase in bone, Biomaterials 29 (2008) 4855-4863. https://doi.org 10.1016/j.biomaterials.2008.09.001

[4] U. Erdem, M. Doga, A. U. Metin, S. Baglar, M. B.Turkoz, M. Turk, S. Nezir, Hydroxyapatite-based nanoparticles as a coating material for the dentine surface: An antibacterial and toxicological effect, Ceramics Int. $46 \quad$ (2020) 270-280. https://doi.org/10.1016/j.ceramint.2019.08.260

[5] R.A. Ramli, R. Adnan, M.A. Bakar, S.M. Masudi, Synthesis and characterisation of pure nanoporous hydroxyapatite; J. Phys. Sci. 22 (2011) 25-37.

[6] G. Gergely, F. Weber, I. Lukacs, A.L.Toth, Z.E. Horvath, J. Mihaly C. Balazsi, Preparation and characterization hydroxyapatite from eggshell. Ceramics Int. 36 (2010) 803-806.

[7] M. Leena, D. Rana, T. J. Webster, M. Ramalingam, Accelerated synthesis of biomimetic nano hydroxyapatite using simulated body fluid, Mater. Chem. Phys. $180 \quad$ (2016) 166-172 https://doi.org/10.1016/j.matchemphys.2016.05.060

[8] G. Zuo, X.Wei; H. Shanshan, L. Peixiao, Z. Xiongfeng, Z.Y. Shen, Morphology controlled synthesis of nano-hydroxyapatite using polyethylene glycol as a template, J. Alloys Comp. 692 (2020) 693-697 https://doi.org/10.1016/j.jallcom.2016.09.117.

[9] L. W. Liu, G. Qian, L. Liu, B. Zhang, X. Fan, A simple method to controlled synthesis of nano hydroxyapatite in different particle size, Mater. Lett. 217 (2018) 177-180. https://doi.org/10.1016/j.matlet.2018.01.079.

[10] K.C.B. Yeong, J. Wang, S. C. Ng, Mechanochemical synthesis of nanocrystalline hydroxyapatite from $\mathrm{CaO}$ and $\mathrm{CaHPO}_{4}$, Biomaterials 22 (2001) 2705-2712. https://doi.org 10.1016/s0142-9612(00)00257-x

[11] S. Khan, M. Pirvani, S. Humayoun, O. Anjum, S. Akram, M. A. Nathani,, Synthesis of nanohydroxyapatite and nano-fluoroapatite particles by sol-gel method, Pak. J. Med. Dent. 8 (2019) 40-44 https://doi.org/10.1016/j.ceramint.2015.11.010

[12] I. Sopyan, R. Singh, M. Hamdi, Synthesis of nanosized hydroxyapatite powder using sol-gel technique and its conversion to dense and porous bodies, Ind. J. Chem. 47A (2008) 1626-1631.

[13] S. Rehman, K. Khan, M. Mujahid, S. Nosheen, Synthesis of nano-hydroxyapatite and its rapid mediated surface functionalization by silane coupling agent, Mater. Sci. Eng. C38 (2016) 675-681. https://doi.org/10.1016/j.msec.2015.09.014

[14] M. N. Hassan, M. M. Mahmoud, A. A. El-Fattah, S. Kandil, Microwave-assisted preparation of nanohydroxyapatite for bone substitutes, Ceramics Int. 42 (2016) 3725-3744. https://doi.org/10.1016/j.ceramint.2015.11.044 
[15] J. Chen, J. Liu, H. Deng, S. Yao, Y. Wang, Regulatory synthesis and characterization of hydroxyapatite nanocrystals by a microwaveassisted hydrothermal method, Ceramics Int. 46 (2020) 2185-2193.

https://doi.org/10.1016/j.ceramint.2019.09.203

[16] A. Esmaeilkhanian, F. Sharifianjazi, A. Abouchenari, A. Rouhani, N. Parvin, M. Irani, Synthesis and characterization of natural nano-hydroxyapatite derived from turkey femur-bone waste, Appl. Biochem. Biotech. 189 (2019) 919-932. https://doi.org/10.1007/s12010-019-03046-6

[17] S. Kehoe, Optimization of hydroxyapatite (HAp) for orthopedic application via the chemical precipitation technique, $\mathrm{Ph}$. $\mathrm{D}$. thesis, School of Mechanical and Manufacturing Engineering, Dublin City University, 2008.

[18] M. Vallet-Regi, Ceramics for medical applications, The Royal Society of Chemistry, Dalton Transactions (2000) 97-108. https://doi.org/10.1039/B007852M

[19]R. Palanivelu, A. Rubankumar, Synthesis and spectroscopic characterization of hydroxyapatite by sol-gel method. Int. J. Chem. Tech. Res. 5 (2013) 2965-2969.

[20] U. Vijayalakshmi and S. Rajeswari, Preparation and characterization of microcrystalline hydroxyapatite using sol gel method. Trends Biomat. Art. Org. 19 (2006) 57-62.

[21] N. Varadarajan, R. Balu, D. Rana, M. Ramalingam, T.S.S. Kumar, Accelerated sonochemical synthesis of calcium deficient hydroxyapatite nanoparticles: structural and morphological evolution. J. Biomat. Tissue Eng. 4 (2014) 295-299. https://doi.org/10.1166/jbt.2014.1173

[22] C. Liu, Y. Huang, W. Shen, J. Cui, Kinetics of hydroxyapatite precipitation at $\mathrm{pH} 10$ to 11 . Biomaterials 22 (2001) 301-306. https://doi.org/10.1016/s0142-9612(00)00166-6

[23] J.L. Acevedo-Davila, I. Lopez-Cuevas, G. VargasGutierrez, J.C. Rendon, J. Mendez-Nonell, Chemical synthesis of bone-like carbonate hydroxyapatite from hen eggshells and its characterization, Boletin de la Sociedad Espanola de Ceramica y Vidrio 46 (2007) 225-231.

[24] N.A. Aal, M. Bououdina, A. Hajry, A. A. Chaudhry, J. A. Darr, A. A. Al-Ghamdi, E.H. ElMossalamy, Y. K. Sung, F. El-Tantawy, Synthesis, characterization and electrical properties of hydroxyapatite nanoparticles by utilization of biowaste eggshells, Biomat. Res. 15 (2011) 52-59.

[25] A. Sobacsak, Z. Kowalski, Z. Wzorek, Preparation of hydroxyapatite from animal bones. Acta Bioeng. Biomechan. 11 (2009) 23-28.

[26] P. Hui, S. L. Meena, G. Singh, R. D. Agarawal, S. Prakash, Synthesis of hydroxyapatite bio-ceramic powder by hydrothermal method. J. Min. Mater. Charact. Eng. 9 (2010) 683-692.

https://doi.org/10.4236/jmmce.2010.98049

[27] M.K. Herliansyah, D.A. Nasution, M. Hamdi, A. Ide-Ektessabi, M.W. Wildan, A.E. Tontowi, Preparation and characterization of natural hydroxyapatite: A comparative study of bovine bone hydroxyapatite and hydroxyapatite form calcite. Mater. Sci. For. 561-564 (2007) 1441-1444. http://dx.doi.org/10.1155/2016/6987218

[28] K. N. A. M. Barakat, M. S. Khil, A. M. Omran, F. A. Sheikh, H. Y. Kim, Extraction of pure natural hydroxyapatite from the bovine bones biowaste by three different methods, J. Mater. Process. Technol. 209

(2009) https://doi.org/10.1016/j.promfg.2015.07.034

[29] K. H. Zuo, Y. P. Zeng, D. Jiang, Effect of polyvinyl alcohol additive on the pore structure and morphology of the freeze-cast hydroxyapatite ceramics. Mater. Sci. Eng. C30 (2010) 283-287. https://doi.org/10.1016/j.msec.2009.11.003

[30] D. K. Pattanayak, P. Divya , S. Upadhyay, R.C. Prasad, B. T. Rao, T. R. R. Mohan, Synthesis and evaluation of hydroxyapatite ceramics. Trends Biomat. Art. Org. 18 (2005) 87-92.

[31] R. Rohim, R. Ahmad, N. Ibrahim, N. Hamidin, C. Z. A. Abidin, Characterization of calcium oxide catalyst from eggshell Waste. Adv. Env. Biol. 8 (2014) 35-38.

[32] T. Nakano, K. Kaibara, Y. Tabata, N. Nagata, S. Enomoto, E. Marukawa, Y. Umakoshi, Unique allignment and texture of biological apatite crystallites in the typical classified tissues analyzed by microbeam X-ray diffractometer system, Bone, 31 (2002) 479-487. https://doi.org/10.1016/s8756-3282(02)00850-5

[33] L. Bernard. M. Freche, J. L. Lacout, B. Biscans, Preparation of hydroxyapatite by neutralization at low temperature: influence of purity of the raw material, Powd. Technol. 103 (1999) 19-25.

[34] J. Venkatean, S. K. Kim, Effect of temperature on isolation and characterization of hydroxyapatite from tuna (Thunnus obesus) bone. Materials 3 (2010) 4761-4772. https://doi.org/10.1016/S0032-5910(99)00009-1

[35] L. Xiaoying, F. Yongbin, G. Dachun, C. Wei, Preparation and characterization of natural hydroxyapatite from animal hard tissues, Key Eng. Mater. 342-343 (2007) 213-216.

[36] M. S. M. Arsad, P. M. Lee, L. K. Hung, Synthesis and characterization of hydroxyapatite nanoparticles and $\beta$-TCP particles, IPCBEE Vol. 7, IACSIT 2011, Singapore.

[37]S.V. Dorozhkin, Calcium orthophosphates as bioceramics: state of the art., J. Func. Biomaterials 31(2010)22-107. 